\title{
Application of low impact development concept in the construction of Shouxian County
}

\author{
Kun Ding ${ }^{1,2, *}$, Yang $\mathrm{Xu}^{1,2}$, Yi Zhang ${ }^{1,2}$, Chen Yang ${ }^{1,2}$ \\ ${ }^{1}$ Anhui Jianzhu University, 230601 Hefei, Anhui, China \\ ${ }^{2}$ Key Laboratory of Huizhou Architecture in Anhui Province, Anhui Jianzhu University, 230601 Hefei Anhui, China
}

\begin{abstract}
Low Impact Development (LID), also known as low impact design or low impact urban design and development, is a rainwater management method based on the principle of simulating natural hydrological conditions, using source control concepts to achieve stormwater control and utilization. Through the analysis of the current topography, meteorology, rainfall, and urban underlying surface of Shouxian County, the author finds out the cause of the county, and proposes to appropriately improve the design standards in the construction of municipal drainage facilities, and learn from the successful experience of sponge city construction in developed countries. The six-character policy of seepage, stagnation, storage, net, use and platoon is implemented in the engineering practice of the county-level recessed green space, rain garden, grass-growing ditch, infiltration pavement and water system remediation. Through several years of implementation, the phenomenon of sea watching in the county has disappeared, the water saving effect is obvious, the greening of the urban landscape has been greatly improved, and the social, economic and environmental benefits have been significantly improved
\end{abstract}

\section{Introduction}

In recent years, with the accelerating process of urbanization in China, the drawbacks of the traditional urban development model have been constantly manifested, and internal disasters have occurred frequently. Many cities have experienced small rains and heavy rains ${ }^{[1]}$, Shouxian County is a typical example. The main reason is that the implementation of relevant national policies and regulations is not in place; the construction standards of the county drainage project are relatively low, the drainage facilities and equipment are aging, and the pipe network is mixed, misconnected and damaged; the maintenance and management of the inland river and the ditch ponds are weak, the encroachment and siltation are serious, and the storage capacity is reduced; hardened ground; rainwater collection and utilization rate is low. Therefore, for the sustainable development of the county, it is not only necessary but also urgent to build a sponge city according to the low-impact development concept.

\section{Analysis of the current situation of Shouxian County}

\subsection{Topography}

The whole territory of Shouxian is dominated by plains and shallow hills, and the terrain is low in the southeast and high in the northwest.

\subsection{Climate}

Shouxian is located in the northern edge of the northern subtropical zone and belongs to the semi-humid monsoon climate zone.

\subsection{Rainfall}

The annual average rainfall is $903.2 \mathrm{~mm}$. The annual maximum rainfall is $1534.1 \mathrm{~mm}$, and the maximum daily rainfall is $109 \mathrm{~mm}$.

\section{4underlying surface analysis}

According to the nature of the underlying surface of the county, it is divided into five categories: residential land, public and commercial service land, industrial and logistics storage land, green space and road and square land.

Shouxian has a special geographical location and frequent floods. The distribution of the main easy points in the central area of Shouxian County is shown in Table 1.

\footnotetext{
$\overline{{ }^{*} \text { Corresponding author: 874408959@qq.com }}$
} 
Table1. the Main easy Points in Shouxian central county

\begin{tabular}{|c|c|c|c|}
\hline $\begin{array}{c}\text { Serial } \\
\text { numbe } \\
r\end{array}$ & Easy position & $\begin{array}{l}\text { Degree } \\
\text { of guilt }\end{array}$ & $\begin{array}{l}\text { Reason for } \\
\text { accumulation }\end{array}$ \\
\hline 1 & $\begin{array}{l}\text { East Street } \\
\text { and North } \\
\text { Street } \\
\text { intersection }\end{array}$ & $\begin{array}{c}\text { submerged } \\
\text { water depth } \\
0.3 \mathrm{~m}, \\
\text { submerged area } \\
1500 \mathrm{~m}^{2}\end{array}$ & $\begin{array}{l}\text { East Street } \\
\text { rain has no } \\
\text { way out }\end{array}$ \\
\hline 2 & $\begin{array}{l}\text { East Street } \\
\text { and North } \\
\text { Crossing } \\
\text { Lane }\end{array}$ & $\begin{array}{c}\text { submerged } \\
\text { water depth } \\
0.5 \mathrm{~m}, \\
\text { submerged area } \\
1000 \mathrm{~m}^{2}\end{array}$ & $\begin{array}{l}\text { East Street } \\
\text { rain has no } \\
\text { way out }\end{array}$ \\
\hline 3 & $\begin{array}{l}\text { East Street } \\
\text { and Inner } \\
\text { Ring Road }\end{array}$ & $\begin{array}{c}\text { submerged } \\
\text { water depth } \\
07 \mathrm{~m}, \\
\text { submerged area } \\
2000 \mathrm{~m}^{2}\end{array}$ & $\begin{array}{c}\text { Low terrain, } \\
\text { unorganized } \\
\text { emissions }\end{array}$ \\
\hline 4 & $\begin{array}{l}\text { East Street } \\
\text { and David } \\
\text { Lane } \\
\text { intersection }\end{array}$ & $\begin{array}{c}\text { submerged } \\
\text { water depth } \\
0.3 \mathrm{~m}, \\
\text { submerged area } \\
800 \mathrm{~m}^{2}\end{array}$ & $\begin{array}{l}\text { East Street } \\
\text { rain has no } \\
\text { way out }\end{array}$ \\
\hline 5 & $\begin{array}{c}\text { North } \\
\text { Liangjia and } \\
\text { Dasi Lane }\end{array}$ & $\begin{array}{c}\text { submerged } \\
\text { water depth } \\
0.4 \mathrm{~m}, \\
\text { submerged area } \\
1000 \mathrm{~m}^{2}\end{array}$ & $\begin{array}{l}\text { Rainwater } \\
\text { pipe diameter } \\
\text { is small }\end{array}$ \\
\hline 6 & $\begin{array}{l}\text { East Street } \\
\text { and Inner } \\
\text { Ring Road }\end{array}$ & $\begin{array}{c}\text { submerged } \\
\text { water depth } \\
0.5 \mathrm{~m}, \\
\text { submerged area } \\
1200 \mathrm{~m}^{2} \\
\end{array}$ & $\begin{array}{c}\text { Low terrain, } \\
\text { unorganized } \\
\text { emissions }\end{array}$ \\
\hline
\end{tabular}

\section{Sponge City Construction Standard}

The low-impact development model based on sustainable urban rainwater system is a rainstorm management method based on ecosystem system and starting from the source of runoff, from blindly "discharge" to "infiltration, storage, stagnation, net, use and drainage". Combine and realize the least impact on the surface runoff of the original natural environment after urban development and construction ${ }^{[2]}$.According to the "Sponge City Construction Technical Guide" --- Low Impact Development Rainwater System Construction, "Shouxian Urban Flood Control Plan", "Anhui Sponge City Rainwater System Control and Utilization" Standard Atlas and "Shouxian County Drainage Project Special Plan" And other regulations, based on the topography, meteorology, hydrology and economic and social development of Shouxian, the criteria for the sponge city in Shouxian are as follows:

(1) The annual total runoff control rate is $70 \% \leq \alpha \leq$ $85 \%$;

(2) In the hardened ground of newly built, rebuilt or expanded squares and parking lots, the permeable pavement rate shall not be less than $40 \%$;

(3) The flood control standard is once in 20 to 50 years, and the drainage standard is once in 20 years.

(4) The green area of the community should not be less than $30 \%$.

\section{LID engineering measures}

The essence of low-impact development is to achieve the common development of environmental protection and urbanization. The foundation of the construction of "sponge city" is to achieve sustainable development ${ }^{[3]}$. LID is suitable for both old city reconstruction and new city development. In combination with the actual situation of Shouxian, it is advisable to adopt some low-impact development models such as planting grass ditch, recessed green space, rain garden, and penetrating the ground.

\subsection{Plant grass ditch}

Increasing vegetation in traditional outdoor surface ditches not only acts as a drainage system, but also beautifies the landscape environment and purifies rainwater runoff.

\section{2 recessed green space}

The concave green space is lower than the surrounding ground, as shown in Figure 1, which is characterized by the use of good infiltration of green space to store rainwater.

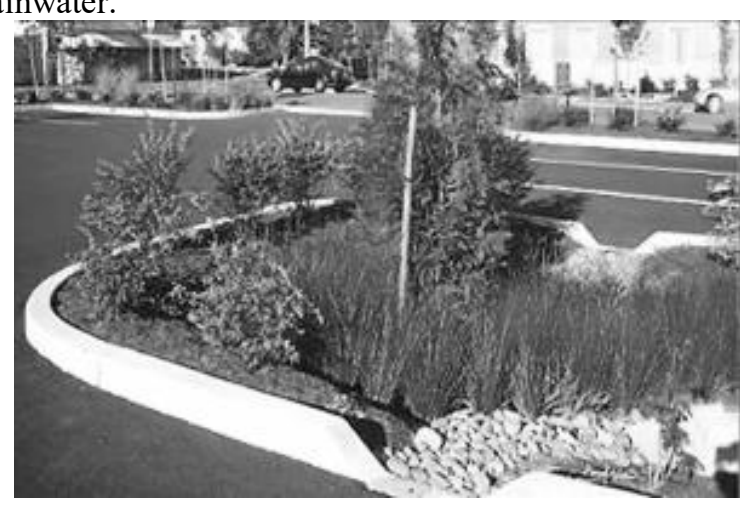

Fig1. Concave green space

\subsection{Rain garden}

Planting trees, flowers and other plants on shallower depressions to form a bioretention pond, namely rain garden, as shown in Figure 2. The rain garden uses the filter medium layer of the plant to remove pollutants, purify the rainwater, temporarily retain the rainwater, and then slowly infiltrate into the soil. Compared with the traditional treatment method, the rain garden has low processing cost and great flexibility in its position, size and aesthetic value ${ }^{[4]}$. Therefore, the urban layout has a greater impact on stormwater control. 

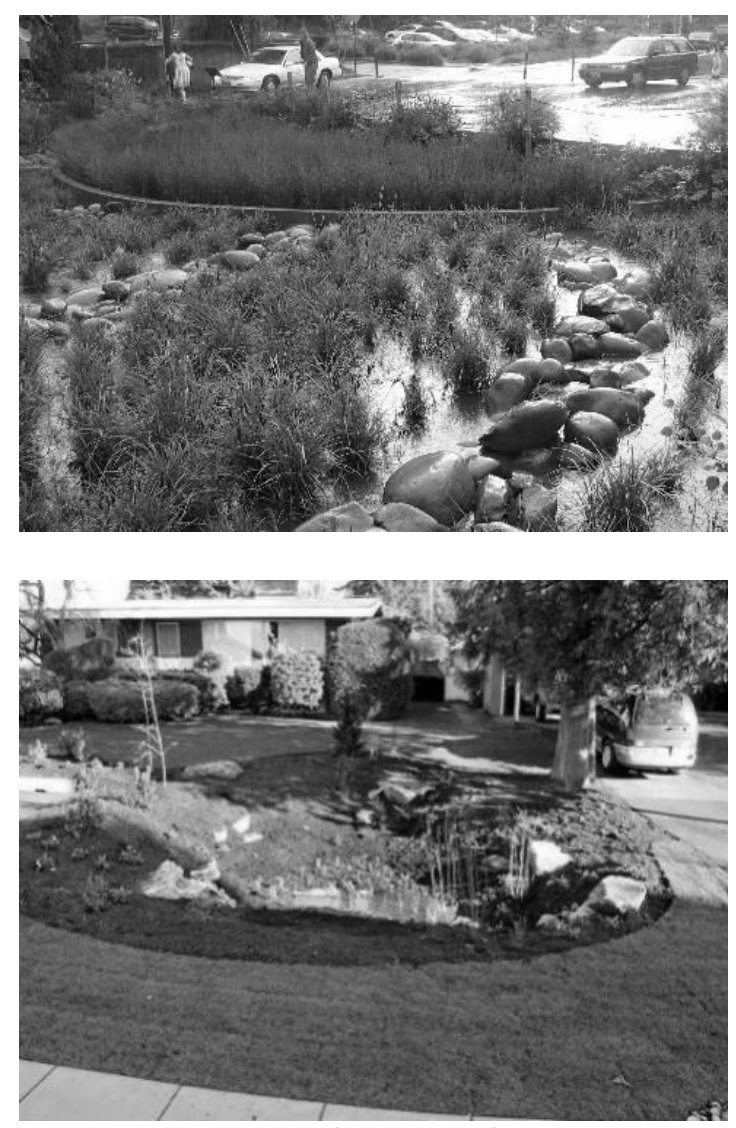

Fig2. Rainwater Garden

\section{4 penetrate the ground}

Infiltration of the ground is mainly divided into two categories, one is porous asphalt and porous concrete floor, and the other is turf brick. The permeable pavement reduces the surface runoff, improves the penetration and penetration speed of the road rainwater, and alleviates the road area water phenomenon.

\section{LID application in Shouxian County}

Foreign developed countries have gained some successful experience in rainwater management. The US low-impact development technology is a green rainwater infrastructure. Through years of engineering practice, there are strict requirements and mature calculation methods in terms of water volume calculation and effluent quality, and during the promotion period, a large number of related companies were cultivated, and a large number of practical products and equipment were developed to mature the industry ${ }^{[5]}$.The UK establishes rainwater harvesting and utilization systems in residential, community and commercial buildings to address the shortage of urban water resources ${ }^{[6]}$. The UK government ensures that SUDS (Sustainable Urban Drainage System) is always a supplement to public open spaces and amenities, rather than hindering their actual use ${ }^{[7]}$.Japan makes full use of the underground space of the city to reduce the floor space of the savings facilities, and requires all newly built public buildings to be equipped with corresponding rainwater infiltration devices ${ }^{[8]}$.Their successful experience provides a good reference for the construction of Shouxian sponge city.

\subsection{Hardened road reconstruction}

The hardened pavement of Shouxian County has impervious water. When rain occurs, the rainwater on the road surface cannot be removed in time, causing water in the road area and causing internal sputum in severe cases. In the construction of the sponge city, the introduction of grass-growing ditch facilitates the timely discharge of accumulated water and alleviates urban shackles.

The rainstorm intensity formula of Shouxian is:

$$
q=\frac{1693.951(1+0.971854 \operatorname{LgP})}{(t+7.691)^{0.689}}
$$

In the middle:q_rain intensity $(\mathrm{L} / \mathrm{s} \cdot \mathrm{ha})$

$$
\mathrm{p} \text {-recurrence period (a) }
$$

Description: The return period of rainwater years, the important area is 5-10 years, the underground passage and sinking square are 20 years.

\begin{tabular}{|c|c|c|c|c|}
\hline $\begin{array}{c}\text { Serial } \\
\text { number }\end{array}$ & Road name & $\begin{array}{c}\text { Green } \\
\text { belt } \\
\text { area } \\
\left(\mathrm{m}^{2}\right)\end{array}$ & $\begin{array}{c}\text { Pipe } \\
\text { diameter } \\
(\mathrm{mm})\end{array}$ & $\begin{array}{c}\text { Governor } \\
\text { (m) }\end{array}$ \\
\hline 1 & $\begin{array}{c}\text { Pearl } \\
\text { Avenue }\end{array}$ & 46400 & $\begin{array}{l}\mathrm{d} 500- \\
\mathrm{d} 2000\end{array}$ & 3220 \\
\hline 2 & $\begin{array}{l}\text { Dongjin } \\
\text { Avenue }\end{array}$ & 64600 & $\begin{array}{l}\text { d500- } \\
\text { d2200 }\end{array}$ & 3610 \\
\hline 3 & $\begin{array}{l}\text { Binyang } \\
\text { Avenue }\end{array}$ & 61100 & $\begin{array}{l}\mathrm{d} 500- \\
\mathrm{d} 2000\end{array}$ & 6110 \\
\hline 4 & $\begin{array}{l}\text { Chudu } \\
\text { Avenue }\end{array}$ & 36120 & $\begin{array}{l}\mathrm{d} 500- \\
\mathrm{d} 2000\end{array}$ & 3612 \\
\hline 5 & $\begin{array}{l}\text { Shouchun } \\
\text { South Road }\end{array}$ & 42250 & $\begin{array}{l}d 500- \\
\text { d1200 }\end{array}$ & 745 \\
\hline 6 & Outer loop & 60500 & $\begin{array}{l}\mathrm{d} 500- \\
\mathrm{d} 2400\end{array}$ & 6050 \\
\hline 7 & $\begin{array}{l}\text { Shouchun } \\
\text { North Road }\end{array}$ & 24000 & $\begin{array}{l}\mathrm{d} 500- \\
\mathrm{d} 2000\end{array}$ & 4000 \\
\hline 8 & $\begin{array}{c}\text { Zhuang } \\
\text { yuan Road }\end{array}$ & 32280 & $\begin{array}{l}d 500- \\
\text { d1000 }\end{array}$ & 5380 \\
\hline 9 & $\begin{array}{c}\text { Binhu } \\
\text { Avenue }\end{array}$ & 14355 & $\begin{array}{l}\text { d500- } \\
\text { d1350 }\end{array}$ & 4785 \\
\hline 10 & Tonglu Road & 23508 & $\begin{array}{l}\mathrm{d} 500- \\
\mathrm{d} 2000\end{array}$ & 3918 \\
\hline 11 & $\begin{array}{l}\text { Anfeng } \\
\text { Road }\end{array}$ & 20820 & $\begin{array}{c}\mathrm{d} 500- \\
\mathrm{d} 800 \\
\end{array}$ & 4380 \\
\hline 12 & $\begin{array}{c}\text { Souhuo } \\
\text { Road }\end{array}$ & 19680 & $\begin{array}{l}\text { d500- } \\
\text { d1200 }\end{array}$ & 1890 \\
\hline 13 & Yuejin Road & 6690 & $\begin{array}{l}\mathrm{d} 500- \\
\mathrm{d} 2000\end{array}$ & 2230 \\
\hline 14 & Soucai Road & 13440 & $\begin{array}{l}\mathrm{d} 1000- \\
\mathrm{d} 2000\end{array}$ & 4480 \\
\hline 15 & $\begin{array}{l}\text { Dinghu } \\
\text { Road }\end{array}$ & 15090 & $\begin{array}{l}\mathrm{d} 500- \\
\mathrm{d} 2000\end{array}$ & 5030 \\
\hline 16 & $\begin{array}{c}\text { Zhongxing } \\
\text { Road }\end{array}$ & 9180 & $\begin{array}{l}\text { d500- } \\
\text { d1200 }\end{array}$ & 2055 \\
\hline
\end{tabular}

Table 2. Shouxian road greening facilities and new rainwater pipe network 


\begin{tabular}{|c|c|c|c|c|}
\hline 17 & $\begin{array}{c}\text { Dashun } \\
\text { Road }\end{array}$ & 8190 & $\begin{array}{c}\mathrm{d} 500- \\
\mathrm{d} 2400\end{array}$ & 980 \\
\hline 18 & $\begin{array}{c}\text { Hidden } \\
\text { Road }\end{array}$ & 13740 & $\begin{array}{c}\mathrm{d} 500- \\
\mathrm{d} 1800\end{array}$ & 560 \\
\hline 19 & Zijin Road & 11640 & $\begin{array}{c}\mathrm{d} 500- \\
\mathrm{d} 2000\end{array}$ & 3030 \\
\hline 20 & $\begin{array}{c}\text { Shimiao } \\
\text { Road }\end{array}$ & 10260 & $\begin{array}{c}\mathrm{d} 500- \\
\mathrm{d} 2000\end{array}$ & 3420 \\
\hline 21 & $\begin{array}{c}\text { Zhenyang } \\
\text { Road }\end{array}$ & 6060 & $\begin{array}{c}\mathrm{d} 500- \\
\mathrm{d} 1350\end{array}$ & 2020 \\
\hline 22 & $\begin{array}{c}\text { Corrugated } \\
\text { road }\end{array}$ & 8160 & $\begin{array}{c}\mathrm{d} 500- \\
\mathrm{d} 2600\end{array}$ & 2720 \\
\hline 23 & $\begin{array}{c}\text { Political } \\
\text { access }\end{array}$ & 14250 & $\begin{array}{c}\mathrm{d} 500- \\
\mathrm{d} 1200\end{array}$ & 4750 \\
\hline 24 & $\begin{array}{c}\text { Yanyuan } \\
\text { Road }\end{array}$ & 13770 & $\begin{array}{c}\mathrm{d} 500- \\
\mathrm{d} 2000\end{array}$ & 4510 \\
\hline 25 & West Loop & 18300 & $\begin{array}{c}\mathrm{d} 500- \\
\mathrm{d} 2100\end{array}$ & 990 \\
\hline 26 & $\begin{array}{c}\text { South Ring } \\
\text { Road }\end{array}$ & 9360 & $\begin{array}{c}\mathrm{d} 500- \\
\mathrm{d} 2000\end{array}$ & 2590 \\
\hline & total & 603743 & & \\
\hline & & & & \\
\hline
\end{tabular}

It can be seen from Table 2 that the greening on both sides of the road in Shouxian County is about $0.604 \mathrm{~km}^{2}$. Through the construction of the road rainwater pipe network, the green belts will be reconstructed by using low-impact development measures such as recessed green space and grass-growing ditch, so that the infiltration area of the converted road is $0.604 \mathrm{~km}^{2}$.

\section{2 parking lot renovation}

The parking lot is paved with permeable floor tiles, the parking space is laid with grass bricks, and the green space next to the road is designed as a rain garden with a gap, which makes the rain garden communicate with the grass. The rainwater runoff penetrates into the ground through the grass, and if there is overflow, it flows into the rain garden on both sides of the road, and the rainwater overflowing from the rain garden flows into the grass ditch. Combined with the current situation of Shouxian County, the newly built and renovated parking lot covers an area of $28,800 \mathrm{~m}^{2}$, effectively intercepting the hardened ground rainwater in the parking lot and alleviating the shackles in the county.

\section{3 green space construction}

Urban green space is an important part of urban ecosystem. With the implementation of the sponge city concept, urban green space can effectively control rainwater runoff as a low-impact development measure [9]. The various green space plans in Shouxian are shown in Table 3 and Figure 3.

Table3. Planning of Shouxian City Park

\begin{tabular}{|c|c|c|c|}
\hline $\begin{array}{c}\text { Serial } \\
\text { number }\end{array}$ & Name & Nature & $\begin{array}{c}\text { Land area } \\
(\mathrm{km} 2)\end{array}$ \\
\hline 1 & Shouchun Park & comprehen & 0.62 \\
\hline 2 & West & special & 0.20 \\
\hline 3 & East & comprehen & 0.29 \\
\hline
\end{tabular}

\begin{tabular}{|c|c|c|c|}
\hline $\begin{array}{c}\text { Serial } \\
\text { number }\end{array}$ & Name & Nature & $\begin{array}{r}\text { Land area } \\
(\mathrm{km} 2)\end{array}$ \\
\hline 4 & Shouchuncheng & special & 0.19 \\
\hline 5 & Northwest & special & 0.25 \\
\hline 6 & Northeast Point & special & 0.16 \\
\hline 7 & Moat park & strip park & 0.79 \\
\hline 8 & Shouhuo Park & strip park & 0.26 \\
\hline 9 & Chengxi Park & strip park & 0.23 \\
\hline 10 & Shouhua Park & strip park & 0.17 \\
\hline 11 & Shouxian Park & strip park & 0.28 \\
\hline 12 & Shoubin Park & strip park & 0.65 \\
\hline 13 & Shouyan Park & strip park & 0.48 \\
\hline 14 & Shounan Park & strip park & 0.15 \\
\hline 15 & other & streetside & 0.97 \\
\hline \multicolumn{3}{|c|}{ total } & 5.69 \\
\hline
\end{tabular}

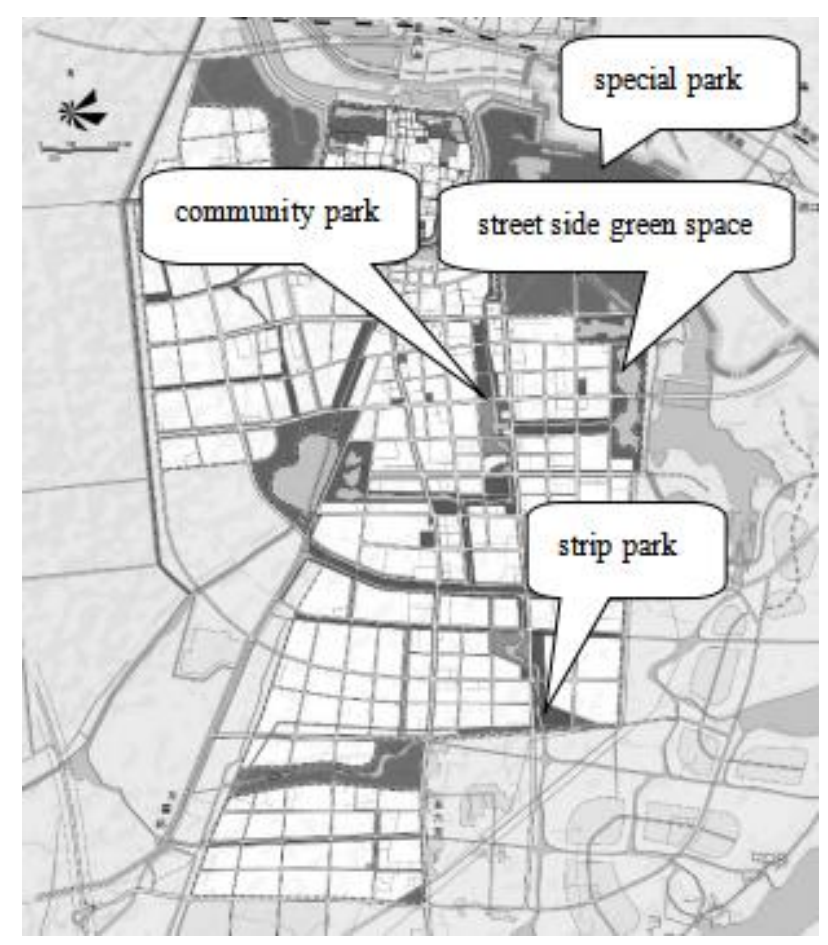

Fig3. Planning Map of Green Space in Shouxian County

According to Table 3, the green land for Shouxian County is $5.69 \mathrm{~km}^{2}$. In the construction of Shouxian green space, control and adjust the relationship between road surface, green space and gully elevation, so that the road surface is higher than the green space, the rainwater outlet is set in the green space, and the green space elevation is lower than the road elevation, so as to form a concave green space, rainwater runoff on paved areas such as roads and buildings first flows into the green space, and the green space fills the water and then flows into the rainwater outlet. Green space construction can not only improve the urban landscape, but also use the stored rainwater for fire protection, tree planting, car washing, flushing toilets and cooling water supply, so that the rainwater can be fully utilized. 


\section{Water system remediation}

The Huaihe River flows from the west to the east, and the Pihe River flows through the Shouxian from the south to the north. The Dongfei River and the Wabu Lake run through the north and south of Shouxian, and Xiaoyan Lake and Liangjia Lake flow into the Huaihe River and the Pihe River respectively. In recent years, Shouxian's social and economic development has been rapid, water pollution has become increasingly serious, and river improvement programs have been continuously updated. See Table 4 for details.

Table4. Shouxian River Road Remediation Measures

\begin{tabular}{|c|c|c|}
\hline $\begin{array}{c}\text { Serial } \\
\text { number }\end{array}$ & River & Remediation measures \\
\hline 1 & Huaihe River & $\begin{array}{c}\text { dredging and section } \\
\text { reconstruction }\end{array}$ \\
\hline 2 & Pihe River & $\begin{array}{c}\text { planting slope protection } \\
\text { plants }\end{array}$ \\
\hline 3 & Dongfei River & $\begin{array}{c}\text { River widening, building } \\
\text { defense }\end{array}$ \\
\hline 4 & Wabu Lake & $\begin{array}{c}\text { using artificial aeration and } \\
\text { reoxygenation technology }\end{array}$ \\
\hline 5 & Xiaoyan Lake & sewage interception \\
\hline 6 & Liangjia Lake & stocking filter fish \\
\hline
\end{tabular}

\section{Conclusion}

In the long run, sponge cities can not only promote urban development, but also improve the quality of urban environment. Therefore, it is imperative to build a sponge city. This paper analyzes the current problems and the root causes of the situation in Shouxian County, and combines the experience of sponge city construction in developed countries, based on the low-impact development concept, proposes feasible design plans and implementation measures for the construction of Shouxian County. It is expected to provide a certain reference for municipal construction in similar cities.

\section{References}

1. N Su. Discussion on the Causes of Urban Water Logging and the Improvement Direction of the Whole Process of Drainage System[J]. CDFP,2019, (2): 136-137.

2. Research on municipal road construction based on LID_-Taking Shuanghu Road in Zhuhai as an example [D]. Southwest Jiaotong University, 2017.

3. YY Tao. The direction and measures of low impact development of garden cities from the perspective of "Sponge City"[J]. XH, 2016(23): 105-106.

4. WM Du, W Deng, JY Li. The Role of Rain-garden in the Whole Rain-water Dispose system[J].VE, 2015(4): 290-291.

5. Urban Green Space System Research under the Sponge City Concept [D]. Qingdao Technological University, 2016.

6. [6] H Yang. Problems and Countermeasures of Natural Drainage System in the Construction of Sponge City in Huizhou City[J]. TTE, 2018, (47): 276-277.

7. Kim E J, Kim T, Paasche-Orlow M K, et al. Disparities in Hypertension Associated with Limited English Proficiency[J].SU, 2017, 32(6):632-639.

8. YZ Lin, HQ Wang, YN Yang, et al. Talking about the Development Status of Building Sponge City[J].REEP, 2019(2).

9. YX Zhang.The Low Impact Development (LID) Technology Overview [J].UR, 2015(9). 